\title{
Lipofuscin in the Cerebellar Cortex of Albino Rats: An Electron Microscopic Study***
}

\author{
H. Heinsen
}

Abt. Anatomie der RWTH Aachen, Melatener Str. 211, D-5100 Aachen, Federal Republic of Germany

\begin{abstract}
Summary. The ultrastructure of autofluorescent, PAS-positive lipofuscin in Purkinje, granule, Golgi epithelial, basket and stellate, microglial and perivascular cells in the cerebellar cortex of senescent rats is described. The membrane-bounded pigment is composed of three elements: 1) electron-lucent homogeneous droplets, 2) a granular matrix and 3) intensely osmiophilic patches. The proportions of these three components vary between cell types and one can grossly differentiate a neuronal and a glial lipofuscin. The lipofuscin granules of stellate and perivscular cells are different from lipofuscin of other cerebellar neurons and glia. It can be concluded from these morphological observations that each cerebellar cell type has its distinct lipofuscin.
\end{abstract}

Key words: Lipofuscin - Cerebellar cortex - Ultrastructure - Senescent rat.

\section{Introduction}

The appearance of a "yellow pigment" in aging cells, especially in strictly postmitotic cells like nerve and muscle cells, has evoked the interest of a great number of investigators since the end of the last century. Several names have been coined for this "yellow pigment" (Obersteiner, 1903) like ceroid, chromolipoid, hemofuscin, neurolipofuscin etc. (for a review see Ciaccio, 1915; Pearse, 1972). Lipofuscin does not generally occur in all nerve cells but there exist nerve cells which accumulate a lot of lipofuscin very early in ontogeny and others which have hardly any lipofuscin. Obersteiner (1903) introduced the terms "lipophobic" and "lipophilic cells" and Altschul (1938) speaks of "pathoklisis" to characterize the agedependent accumulation of lipofuscin in different regions of the central nervous system. The origin and possible significance of lipofuscin remain uncertain. Attempts to analyze the chemical composition of lipofuscin (Heidenreich and Siebert, 1955; Hendley, Mildvan, Reporter and Strehler, 1963; Björkerud, 1964;

* Supported by the Deutsche Forschungsgemeinschaft La 184/5

** I would like to thank Mrs. v. Bronewski and Mr. H. Boffin for their technical assistance 
Koeppen, Barron and Cox, 1971) have yielded different results. Furthermore, the question of whether lipofuscin is a "wear and tear pigment" or has some important functions in cell metabolism (Karnaukhov, Tataryunas and Petrunyaka, 1972), is not settled. For a review on this problem the reader is referred to the articles of Brizzee et al. (1975) and Braak (1971). Histochemical and electron microscopic observations have shown the presence of acid phosphatase and other hydrolases in lipofuscin (Gedigk and Bontke, 1956; Gedigk and Fischer, 1959; Goldfischer, Villaverde and Forschirm, 1966; Goldfischer and Bernstein, 1969; Colcolough, Helmy and Hack, 1970; Brunk and Ericsson, 1972) as well as proteins and lipids (Lubarsch, 1922; Bethe and Fluck, 1937; Braak, 1971; Nandy, 1971). These findings indicate that lysosomes are probably concerned in the genesis of lipofuscin. Electron microscopic observations have revealed the presence of three components which make up lipofuscin granules: An intensely osmiophilic mass, a fine granular matrix and an electron lucent globular material (Christensen, 1965; Roy and Wolman, 1969). Other authors have described only two components in the lipofuscin granules (Hess, 1955; Gonatas, Terry, Winkler, Korey, Gomez and Stein, 1963; Miyagashi, Takahata and lizuka, 1967; Hirosowa, 1968; Borit, Rubinstein and Urich, 1975; Brizzee, Harkin, Ordy and Kaack, 1975). D'Agostino and Luse (1964) tried to establish a difference in the composition between lipofuscin and neuromelanin, neuromelanin having a striate crystalline pattern, but Duffy and Tennyson (1965), Roy and Wolman (1969) and Singer, Cate, Ross and Netsky (1974) did not see any significant difference between the structure of melanin granules and lipofuscin, Barden (1975) reviews the possible relationship between melanin granules and lipofuscin pigment and Barden and Martin (1972) designate neuromelanin as melanized lipofuscin. Lipofuscin in the present study is defined by using the criteria of PAS-positivity, yellow autofluorescence and the presence of electron-lucent droplets, a granular matrix, intensely osmiophilic patches (Christensen, 1965; Frank and Christensen, 1968; Roy and Wolman, 1969) or lamellated bodies like those described by Miyagashi, Takahata and lizuka(1967) and Siakotos and Koppang (1973).

\section{Materials and Methods}

The cerebella of 9 albino rats were examined by light and electron microscopy. One 12 months (female Sprague-Dawley rat) and two 30 months (one male and one female Sprague-Dawely rat) old rats were killed by Nembutal and the cerebella were fixed in formol $10 \%$ (e.g. 1 part of $37 \%$ aqueous formaldehyde is diluted in 4 parts of distilled water cf. Romeis, 1948) and Bouin's solution (Romeis, 1948). The cerebella were embedded in paraffin, cut at $8 \mu \mathrm{m}$ and stained with gallocyanin-chromalum and PAS-light green-hematoxylin (Romeis, 1948). The gallocyanin-chromalum stained tissue was examined by fluorescence microscopy using a BG 12 exciting filter and a $490 \mathrm{~nm}$ barrel filter (Firma Leitz). The precise position and distribution of autofluorescent granules in various cerebellar neurons and glial cells could be studied easily.

Three 25 months (I thank Firma Bayer-Wuppertal for providing us with two female and one male Wistar rats) and two 33 months (one male and one female Sprague-Dawely rats) old rats were deeply anesthesized by Nembutal ( $50 \mathrm{mg}$ Nembutal per $1 \mathrm{~kg}$ body weight), the thorax was quickly opened and the animals were perfused through the left ventricle. The same fixation fluid and postfixation procedures were used as described by Palay and Chan-Palay (1974). Tissue slabs were embedded into Araldite and ultrathin sections were stained with uranyl acetate and lead citrate and examined with a Philips EM 300 electron microscope. 

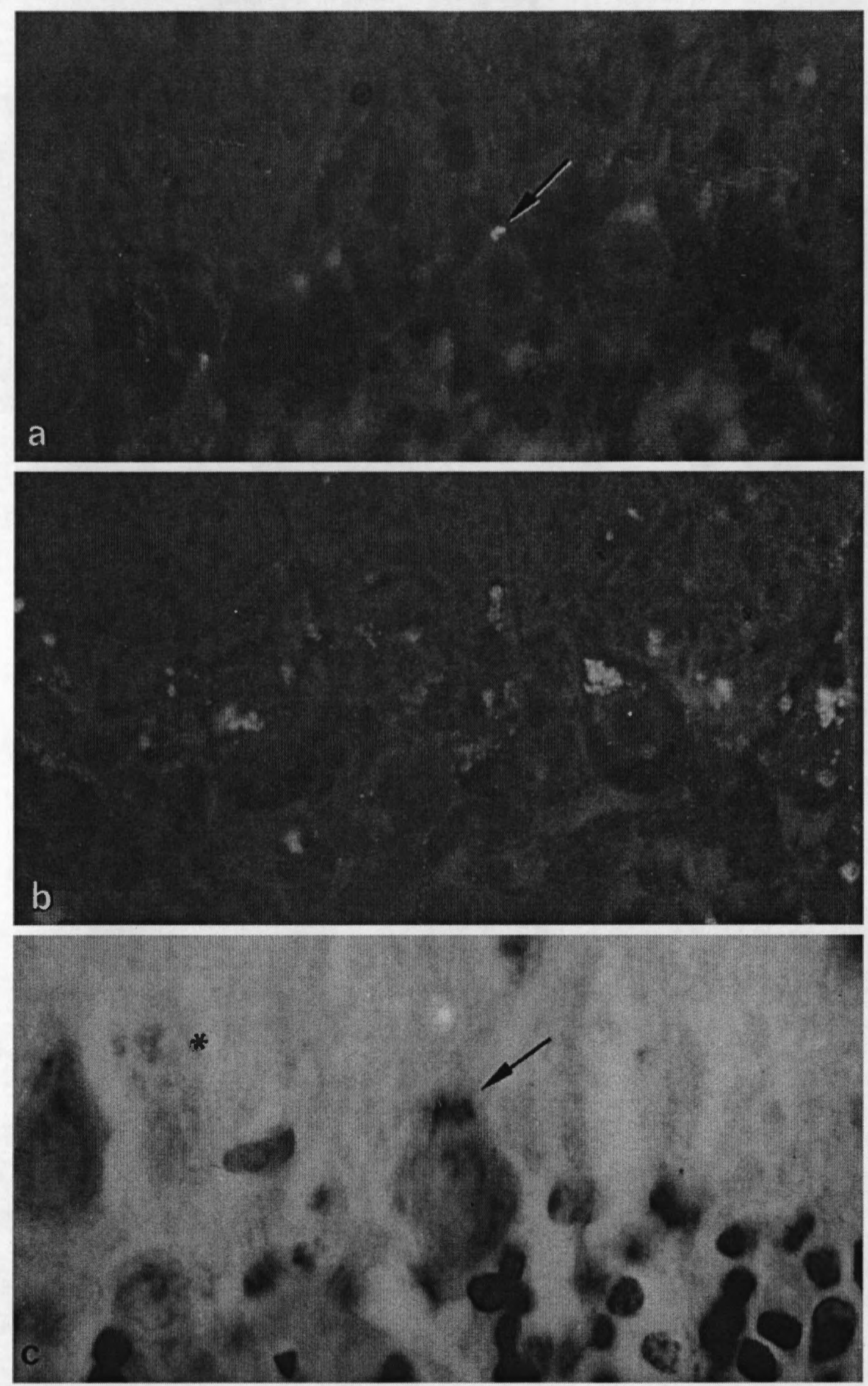

Fig. 1. a Lobule IX b, one year old rat. Gallocyanin-chromalum stained paraffin section. Fluorescence microscope. Arrow points to fluorescent granules in the upper pole of a Purkinje cell. $\times 600$. b Lobule IX b, 30 months old rat. Same technical procedure as Fig. 1 a. Note the rather conspicuous autofluorescent masses in Purkinje cells and the presence of autofluorescent granules of various size and shape in the region of the Purkinje cell layer. $\times 600$. $\mathrm{c}$ Lobule VII, 30 months old rat. PAS-light green-hematoxylin stained paraffin section. Arrow points to PAS-positive material in the upper pole of a Purkinje cell. Asterisks indicate the presence of dust-like fine PAS-positive inclusions between the two Purkinje cells. $\times 1000$ 


\section{Light Microscopic Observations}

The most sensitive method for demonstrating the presence of lipofuscin is the use of a fluorescence microscope equipped with a BG 12 exciting filter and a $490 \mathrm{~nm}$ barrel filter. In a one year old rat, very small but intensely yellow autofluorescent particles in a few Purkinje cells could be identified (Fig. 1 a). Only 15-20 Purkinje cells in each section through the cerebellar vermis contained such particles, which were nearly always located at the upper pole of the cell. The situation is quite different in rats older than 30 months. Figure $1 \mathrm{~b}$ shows a section through a similar region to Figure 1a. Clusters of yellow-orange autofluorescent material are readily found in the perikarya of nearly every Purkinje cell, mainly near the origin of the main dendrite. The clusters occupy a slightly eccentric position between the nucleus and the conical main dendrite. Smaller autofluorescent spots can be found in all parts of the Purkinje cell perikaryon, but smaller particles appear to coalesce with the larger polar clusters. The dendrites of the Purkinje cells are free of pigment. Dust-like dots of autofluorescent material are disseminated between the row of the Purkinje cell perikarya extending from the upper border of the granular layer into the lower third of the molecular layer. In the molecular layer, the dots are grouped together and the long axis of this formation runs parallel to the main dendrites of the Purkinje cells. The nuclei of Bergmann glial can be found in the space between the Purkinje cells and near the dust-like autofluorescent material. Single granules of intermediate size can be observed in close association with the nuclei of neurons of the molecular layer which are probably basket or deep stellate neurons; they become rare in the middle of this layer and are hardly ever seen in its upper third (Fig. 1b). Very small, single granules are uniformly distributed in the granular layer; they lie near the nuclei of granule cells. These fine granules are not seen Figure $1 \mathrm{~b}$, because the coarse grain of the highly sensitive film obscures these delicate structures.

Further coarse clusters of autofluorescent material may be found in all cerebellar layers including the medullary layer and the pial surface of the molecular layer or in the fissures between adjacent lobules. These clusters sometimes form rather conspicuous foci or deposits, mainly in the upper granular layer. The deposits are always situated perivascularly.

The distribution of PAS-positive material was similar to that of the autofluorescent material. PAS-positive clusters in the upper pole of Purkinje cells were easily identified. It was more difficult to observe a dust-like material between the Purkinje cells (Fig. 1c). No PAS-positive material was found near the nuclei of granule cells. Irregularly shaped and rather conspicuous coarse PAS-positive clusters could be seen in perivascular positions. Globules, $0.3-1 \mu \mathrm{m}$ in diameter, could be identified within the large clusters. A core of yellow material could be distinguished within these globules.

\section{Electron Microscopic Observations}

Intensely osmiophilic granules can be identified in the upper pole of the Purkinje cell between the nucleus and the base of the main dendrite in low-power micrographs of 25 months old rats (Fig. 2). A similar osmiophilic granule is seen 


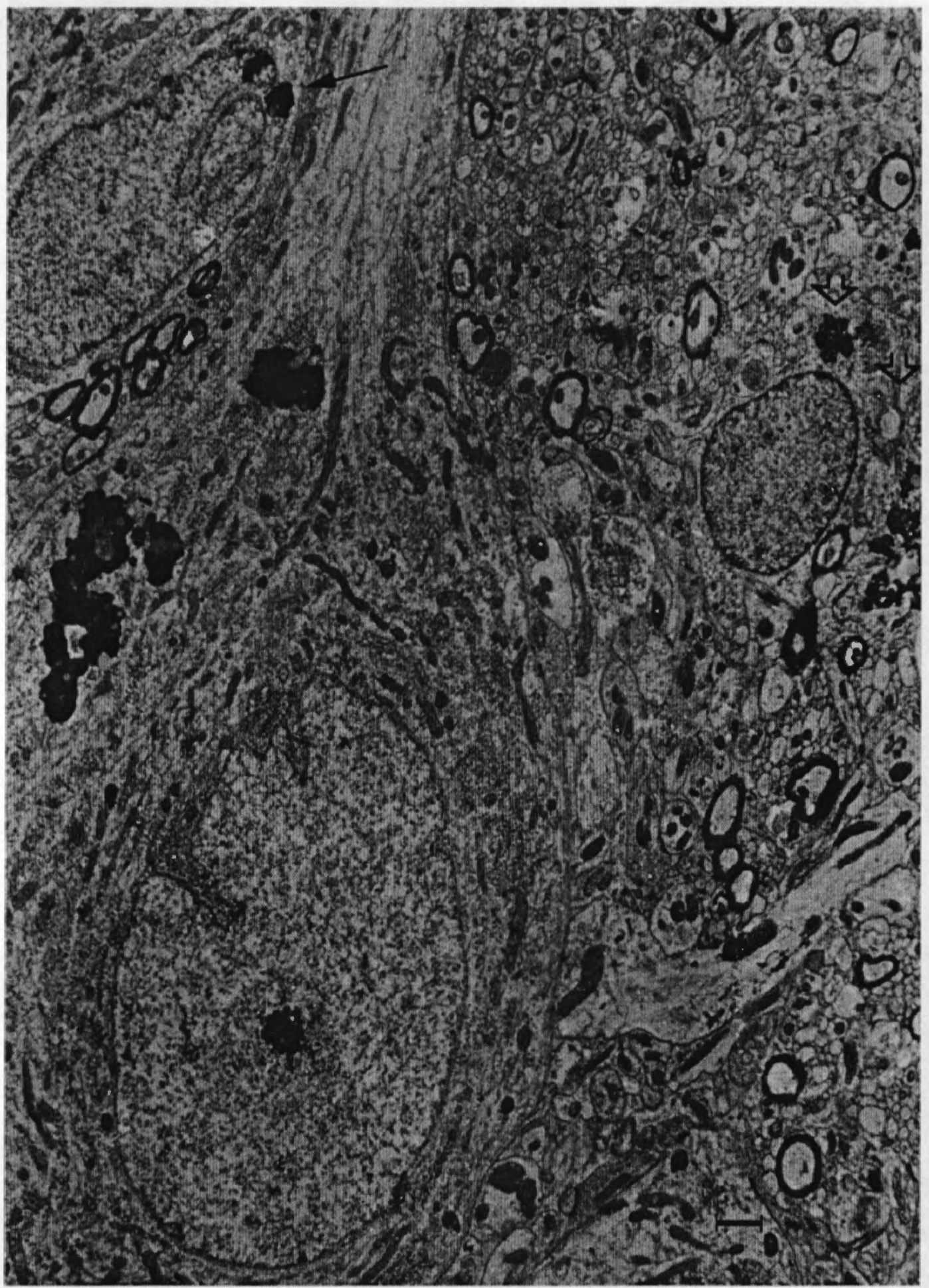

Fig. 2. Ganglionic layer of a 25 months old rat. Note the presence of intensely osmiophilic granules in the upper pole of the Purkinje cell. Arrow points to a lipofuscin granule in a basket cell. Arrowheads at the right side indicate lipofuscin inclusions in Golgi epithelial cells. Lobule VIII, hemispheric part. Bar represents $1 \mu \mathrm{m}$ 
above the nucleus of the adjacent basket cell (Fig. 2, arrow). Further light osmiophilic inclusions can be seen in the cytoplasm of Golgi epithelial cells (Fig. 2, arrow-heads).

The large membrane-bounded osmiophilic granules in Purkinje cells are composed of three elements (Fig. 3a). 1) A finely granular matrix makes up the greatest part; no regular or crystalline substructure can be identified within this matrix. 2) Vesicles of variable diameter with a light internal matrix lie dispersed in the granular matrix. Sometimes, it seems as if these vesicles are becoming enclosed within the dark granular mass. They are regularly surrounded by a dark rim which extends into the light matrix of the droplets thus forming a poorly delimited margin. 3) Dark-black dots which lack any internal structure are irregularly scattered in the granular matrix.

Similar membrane-bounded formations may occur near the nuclei of granule cells (Fig. 3b). The greatest part of these particles is made up by a coarsely granular matrix which contains one or two smaller vesicles with a lighter matrix, or, as in this case, a larger vesicle which seems just about to enter the granule. Dark-black dots like those in the Purkinje cell granules are not frequently encountered, or rather, it is difficult to recognize the dots within the coarsely granular matrix.

The lipofuscin granules of Purkinje and granule cells offer a rather uniform aspect which varies, if at all, by the predominance of the granular or dark-black component. This is not the case for the neurons of the molecular layer. No attempt was made, here, to distinguish deep stellate from basket cells since their ultrastructure is similar. There is, however, a difference between lipofuscin granules of deep and more superficial stellate cells. The amount of lipofuscin depends on the position of neurons in the molecular layer. It is evident from fluorescence microscopy that the deep neurons show a marked autofluorescence whereas the superficial stellate cells do not contain appreciable amounts of autofluorescent material (Fig. 1 b). The lipofuscin of deep stellate and basket cells can be regularly found at one pole near the nucleus where the perikaryal organelles collect. The lipofuscin granules of deep neurons of the molecular layer are sharply delimited from the cytoplasm by a membrane. This is also the case in Purkinje and granule cells. The internal structure of the lipofuscin granules, however, differs in some details from that in Purkinje and granule cells (Fig. 3c). As in Purkinje and granule cells, lighter vesicles with an intensely osmiophilic rim and dark-black patches may be observed, but there exist only faint indications of a granular matrix. The major part of the granules is composed of lamellar structures at the periphery which lose their regular arrangement toward the centre of the lipofuscin body and flow together to form compact osmiophilic patches. Cystic structures with an outer and inner membrane are frequently fused with the lipofuscin granules and surrounded by the membrane of the granules (Fig. 3c).

The lipofuscin granules of more superficially located stellate neurons occupy the perinuclear region, adjacent to Golgi apparatus, endoplasmic reticulum and mitochondria. The granules are sharply delimited by a membrane from the surrounding cytoplasm. The membrane encloses a whorl of lamellae, which are arranged in a finger-print like pattern and show a periodicity of $222 \AA$ (Fig. 4a). A cystic structure, resembling that described in Figure $3 c$, lies at the periphery of the lipofuscin granule enclosed by a membrane, showing signs of progressive condensation. 

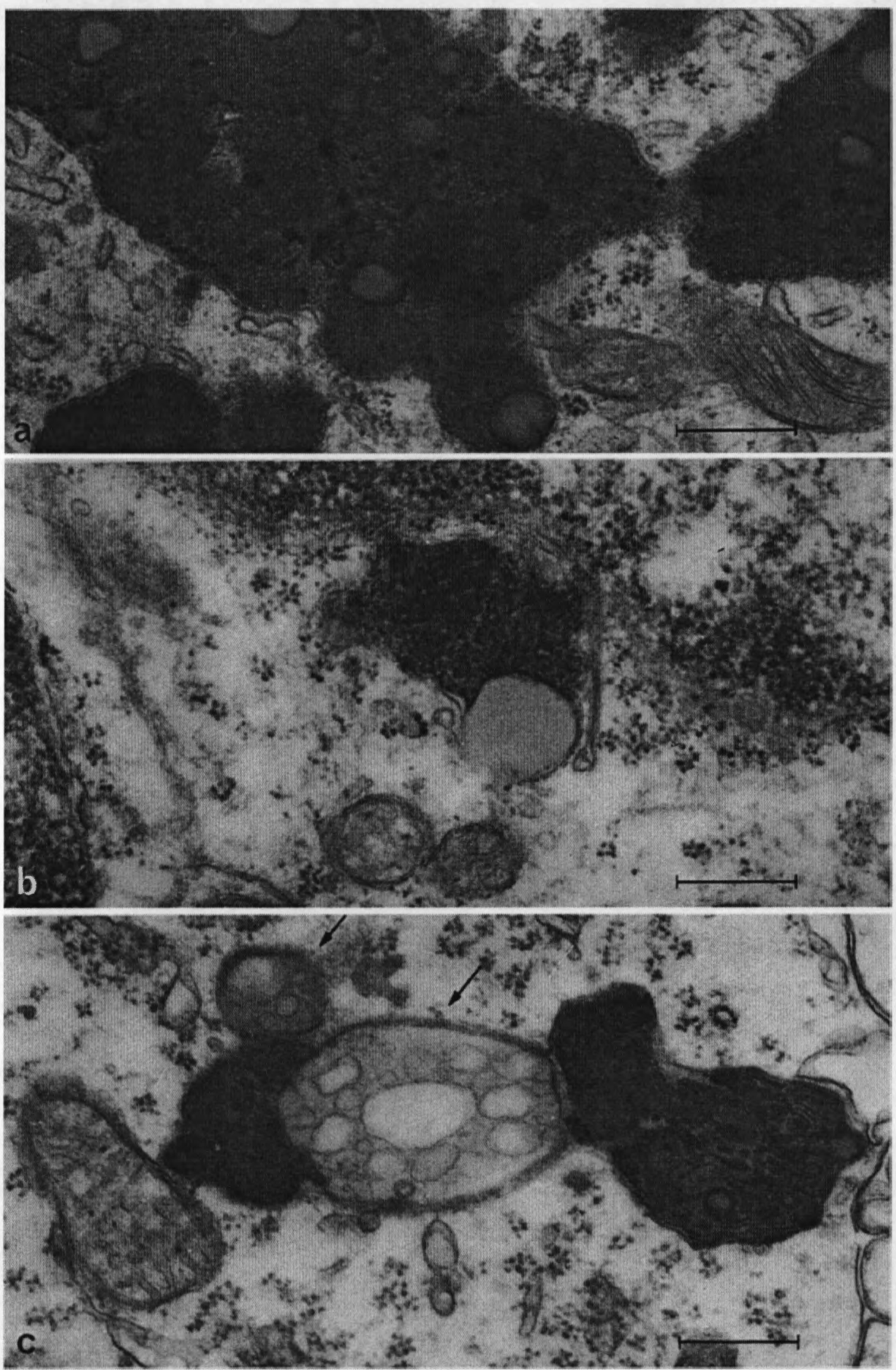

Fig. 3. a Lipofuscin granules of a Purkinje cell at higher magnification. b Lipofuscion of a granule cell. c Lipofuscin of a deep stellate cell. Arrows point to presumed stages of mitochondrial transformation and inclusion into lipofuscin granule. Bars in Figure $3 \mathrm{a}-\mathrm{c}$ represent $0.5 \mu \mathrm{m}$ 

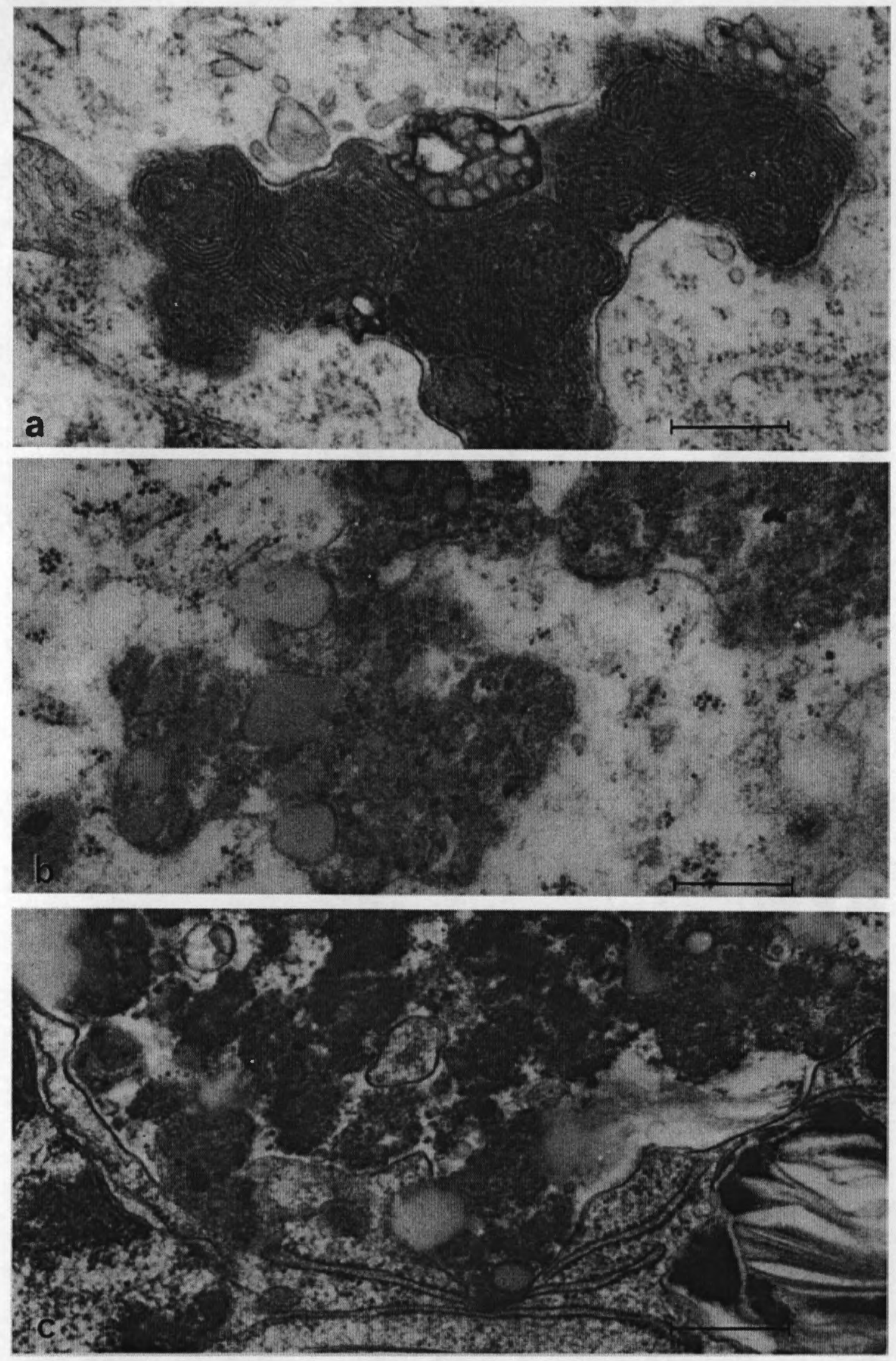

Fig. 4. a Intermediate stellate cell. Finger-print like arrangement of lamellae is recognizable. b Lipofuscin inclusion in a Golgi epithelial cell. cPart of the cytoplasm of a microglial cell. Rat 33 months. Lobule DX a. Bars in Figure 4a-c represent $0.5 \mu \mathrm{m}$ 


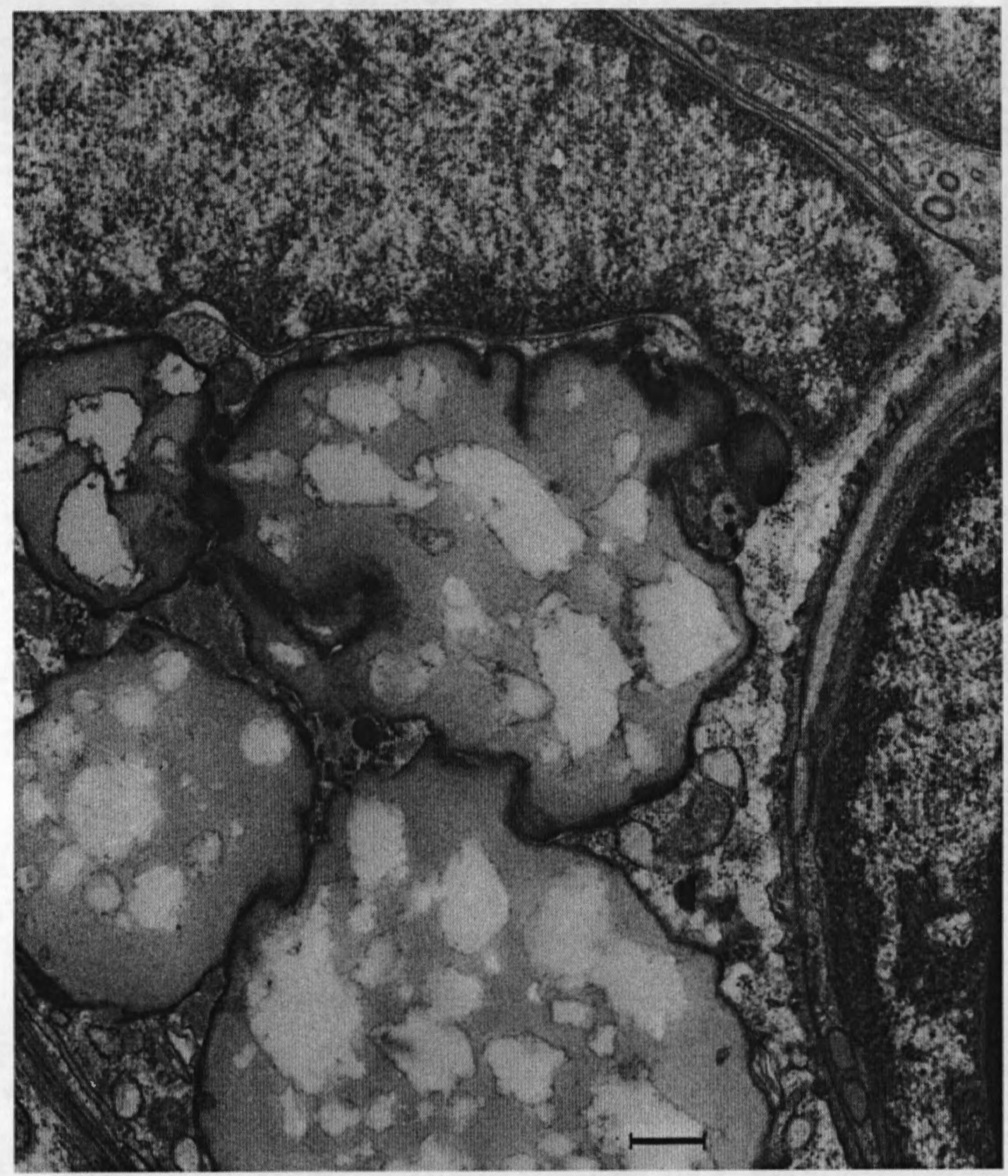

Fig. 5. Pericyte from a larger blood vessel in the upper granular layer. Rat 33 months. Lobule DX. Bar represents $0.5 \mu \mathrm{m}$

Lipofuscin inclusions of various sizes and shapes are scattered within the cytoplasm of Golgi epithelial cells (Fig. 4b). Overall, the lipofuscin inclusions of Golgi epithelial cells are less osmiophilic than the lipofuscin granules of neurons. A membrane surrounds the widely scattered inclusions. Vesicles with a light, homogeneous matrix and osmiophilic cap are the prominent feature of the Golgi epithelial cell lipofuscin (Fig. 4b). Dark osmiophilic patches lie within a light granular matrix.

Microglial cells, the processes of which run parallel to the main dendrites of Purkinje cell or curve around the soma of these neurons, are mainly found in the 
lower molecular layer. They display conspicuous accumulations of lipofuscin (Fig. 4c); the prominent elements are light vesicles with an occasional black rim. A granular matrix contains dark-black osmiophilic patches. A membrane surrounds the lipofuscin inclusions, which are loosely arranged as in Golgi epithelial cells. Besides, various structures, resembling collapsed membranes or organelles, lie in the vicinity of microglial lipofuscin inclusions. They contribute, together with the lipofuscin inclusions, to the highly complex appearance of microglia.

Autofluorescent, PAS-positive perivascular clusters and foci of lipofuscin are identified as huge creased globular inclusions within the cytoplasm of pericytes (Fig. 5). The globular inclusions occupy almost all of the sparse cytoplasm pushing away the nucleus to the periphery of the cell and filling the space between nucleus and vascular basement membrane. A dark osmiophilic rim covers most of the globules' surface. Dark-black osmiophilic spherical bodies are situated between the large globules. A granular matrix, if present, is sparse.

\section{Discussion}

Autofluorescent lipofuscin is present in rather appreciable amounts in cerebellar Purkinje cells in rats older than 25 months. The own autofluorescent studies confirm the observations of other authors who described lipofuscin in the Purkinje cells of horse (Kikuchi, 1928), rhesus monkey (Tcheng, 1964), pig (Whiteford and Getty, 1966; Nanda and Getty, 1971), man (Leibnitz and Wünscher, 1967), rat (Reichel, Hollander, Clark and Strehler, 1968) and mouse (Samorajski, Ordy and Rady-Reimer, 1968). Purkinje cells should therefore not longer be designated as 'lipophobic cells' (Obersteiner, 1903). Furthermore, nearly all other cerebellar neurons and glial cells contain autofluorescent particles in senescent rats with lipofuscin accumulation immediately above and below the Purkinje cell layer. Likewise, the cerebellar cortex is not lipophobic.

In electron microscopy, two types of lipofuscin can be grossly distinguished in the cerebellar cortex: a neuronal and a glial type (Neuronal type in Figs. $3 a-c$; glial type in Figs. $4 \mathrm{~b}, \mathrm{c})$. A common denominator for the neuronal lipofuscin granules is the sharp demarcation from the surrounding cytoplasm by a membrane and the deposition of lipofuscin near Golgi apparatus, endoplasmic reticulum and mitochondria. Gedigk and Wessel (1964) call these regions "Propigmentzonen". The internal structure of neuronal lipofuscin varies depending on the cell type. The ultrastructure of lipofuscin of Purkinje and granule cells is similar to that described by Christensen (1965) and Frank and Christensen (1968) in interstitial cells of the guinea pig testis and by Roy and Wolman (1969) in the substantia nigra of Parkinsonian patients. Lipofuscin granules of basket and stellate cells, on the other hand, exhibit regular lamellated finger-print like structures and resemble lipofuscin types as observed by Miyagashi, Takahata and Iizuka (1967) in the cerebral cortex of senescent and Vitamin E deficient rats and Siakotos and Koppang (1973) in tissue homogenates of brain, heart and liver.

Lipofuscin inclusions of cerebellar Golgi epithelial cells do not prefer certain regions in the cytoplasm but are obviously randomly distributed in the cytoplasm. Lipofuscin inclusions in microglial cells may occupy almost the entire cytoplasm. In 
both cell types, lipofuscin is either deposed as flat irregularly shaped discs or as larger bodies which are deeply creased by the surrounding cytoplasm. It can be concluded that, besides the gross types of neuronal and glial lipofuscin, there exist several subtypes of lipofuscin in individual cerebellar neurons and glial cells, characterized by diameter, shape and internal structure. The present results confirm the observations of Braak (1971) in the inferior olive and dentate nucleus, Siakotos et al. (1972) in brain homogenates and Schlote and Boellaard (1975) in the cerebral cortex, medial thalamic nucleus and dentate nucleus of man.

The question arises, which factors may contribute to the different ultrastructure of lipofuscin. Intracellular neuronal fibrils, Golgi apparatus, endoplasmic reticulum, mitochondria and lysosomes have all been considered as possible precursors of lipofuscin (for a review see Hasan and Glees, 1972). Glees and coworkers (Hasan and Glees, 1973; Gopinath and Glees, 1974; Glees, Spoerri and El-Ghazzawi, 1975) strongly favour the mitochondrial genesis of lipofuscin. The cystic bodies with an inner and outer membrane in Figures $3 \mathrm{c}$ and $4 \mathrm{a}$ may perhaps represent stages in mitochondrial swelling, inclusion into lipofuscin granules and degeneration.

A further factor, the chronological appearance of lipofuscin, must be kept in mind as responsible for lipofuscin polymorphy. Lipofuscin granules in Purkinje cells are rather dark and show no regular internal structure, whereas granules in intermediate stellate cells show a highly regular pattern. Perhaps it may be concluded from the present autofluorescence and ultrastructural observations that lipofuscin "ages" (see also Nandy, 1971) and the dark black freckle-like patches represent neuromelanin, which is, according to Barden (1969) and Barden and Martin (1972) "melanized lipofuscin". Siakotos and Koppang (1973) suggest that the heterogeneous types of lipofuscin represent different developmental stages in the biogenesis of brain lipofuscin.

The inclusions in perivascular cells differ from neuronal and glial lipofuscin because they have few if any granular osmiophilic parts. Wall (1973) describes a perivascular cell type which is mainly found in the Purkinje cell layer of cat, man and rat. The morphology of this cell, its position, fluorescence and histochemical properties resemble, too, pericytes, described in the present study. Probably, these cells are identical with those around the adventitia of brain vessels, which Obersteiner (1903) mentioned in the brain of newborn children and Fleischhauer (1964) extensively described in the brain of young adult and old cats. Wall tries to establish a lipofuscin-transporting system within the cerebellar cortex of cat. The results of the present study cannot exclude such a lipofuscin-transporting system in rat but it would imply that neuronal lipofuscin inclusions have to undergo considerable ultrastructural changes to be transported in cerebellar glial cells.

\section{References}

Altschul, R.: U'ber das sogenannte "Alterspigment" der Nervenzellen. Virchows Arch. path. Anat. 301, 273-286 (1938)

Barden, H.: The histochemical relationship of neuromelanin and lipofuscin. J. Neuropathol. Exp. Neurol. 28, 419-441 (1969)

Barden, H.: The histochemical relationships and the nature of neuromelanin. In: Aging, Volume 1, (H. Brody and J.M. Ordy, eds.) pp. 79-117. New York: Raven Press 1975 
Barden, H., Martin, E.: Electron probe microanalysis of neuromelanin and lipofuscin. In: Pigmentation: Its genesis and biological control (V. Riley, ed.), pp. 631-638. New York: AppletonCentury-Crofts 1972

Bethe, A., Fluck, M.: Über das gelbe Pigment der Ganglienzellen, seine kolloid-chemischen und topographischen Beziehungen $\mathrm{zu}$ anderen Zellstrukturen und eine elektive Methode zu seiner Darstellung. Z. Zellforsch. 27, 211-221 (1937)

Borit, A., Rubinstein, L.J., Urich, H.: The striatonigral degenerations, putaminal pigments and nosology. Brain 98, 101-112 (1975)

Björkerud, S.: Studies on lipofuscin granules of human cardiac muscle. II. Chemical analysis of the isolated granules. Exp. Mol. Pathol. 3, 377-389 (1964)

Braak, H.: Uber das Neurolipofuscin in der unteren Olive und dem Nucleus dentatus cerebelli im Gehirn des Menschen. Z. Zellforsch. 121, 573-592 (1971)

Brizzee, K.R., Harkin, J., Ordy, J.M., Kaack, B.: Accumulation and distribution of lipofuscin, amyloid and senile plaques in the aging nervous system. In: Aging, Volume 1 (H. Brody, D. Harman, J.M. Ordy, eds.), pp. 39-78. New York: Raven Press 1975

Brunk, U., Ericsson, J.L.E.: Electron microscopical studies on rat brain neurons. Localization of acid phosphatase and mode of formation of lipofuscin bodies. J. Ultrastruct. Res. 38, 1-15 (1972)

Christensen, A.K.: The fine structure of testicular interstitial cells in guinea pigs. J. Cell Biol. 26, 911-936 (1965)

Ciaccio, C.: Untersuchungen über die Autooxydation der Lipoidstoffe und Beitrag zur Kenntnis einiger Pigmente (Chromolipoide) und Pigmentkomplexe. Biochemische Zeitschrift 69, 313-333 (1915)

Colcolough, H.L., Helmy, F.M., Hack, M.H.: Some histochemical observations on the lipofuscin of vertebrate liver, kidney and cardiac muscle. Acta histochem. 35, 343-356 (1970)

D'Agostino, A.J., Luse, S.A.: Electron microscopic observations on the human substantia nigra. Neurology 14, 529-536 (1964)

Duffy, P.E., Tennyson, V.M.: Phase and electron microscopic observations of Lewy bodies and melanin granules in the substantia nigra and locus caeruleus in Parkinson's disease. J. Neuropathol. Exp. Neurol. 24, 398-414 (1965)

Fleischhauer, K.: Über die Fluoreszenz perivasculärer Zellen im Gehirn der Katze. Z. Zellforsch. 64, 140-152 (1964)

Frank, A.L., Christensen, A.K.: Localization of acid phosphatase in lipofuscin granules and possible autophagic vacuoles in interstitial cells of the guinea pig testis. J. Cell Biol, 36, 1-13 (1968)

Gedigk, P., Bontke, E.: Über den Nachweis von hydrolytischen Enzymen in Lipopigmenten. Z. Zellforsch. 44, 495-518 (1956)

Gedigk, P., Fischer, R.: Uber die Entstehung von Lipopigmenten in Muskelfasern. Untersuchungen beim experimentellen Vitamin-E-Mangel der Ratte und an Organen des Menschen. Virchows Arch. path. Anat. 332, 431-468 (1959)

Gedigk, P., Wessel, W.: Elektronenmikroskopische Untersuchung des Vitamin-E-Mangel-Pigmentes im Myometrium der Ratte. Virschows Arch. path. Anat. 337, 367-382 (1964)

Glees, P., Spoerri, P.E., El-Ghazzawi, E.: An ultrastructural study of hypothalamic neurons in monkeys of different ages with special reference to age related lipofuscin. J. Hirnforsch. 16, 379-394 (1975)

Goldfischer, S., Bernstein, J.: Lipofuscin (aging) pigment granules of the newborn human liver. J. Cell Biol. 42, 253-261 (1969)

Goldfischer, S., Villaverde, H., Forschirm, R.: The demonstration of acid hydrolase, thermostabile reduced diphosphopyridine nucleotide tetrazolium reductase and peroxidase activities in human lipofuscin pigment granules. J. Histochem. Cytochem. 14, 641-652 (1966)

Gonatas, N.K., Terry, R.D., Winkler, R., Korey, S.R., Gomez, CJ. Stein, A.: A case of juvenile lipidosis: The significance of electron microscopic and biochemical observations of a cerebral biopsy. $J$. Neuropath. Exp. Neurol. 22, 557-580 (1963)

Gopinath, G., Glees, P.: Mitochondrial genesis of lipofuscin in the mesencephalic nucleus of the V nerve of aged rats. Acta anat. 89, 14-20 (1974)

Hasan, M., Glees, P.: Genesis and possible dissolution of neuronal lipofuscin. Gerontologia 18, 217-236 (1972)

Hasan, M., Glees, P.: Lipofuscin in monkey lateral geniculate body, an electron microscope study. Acta anat. 84, 85-95 (1973)

Heidenreich, O., Siebert, G.: Untersuchungen an isoliertem unverändertem Lipofuszin aus Herzmuskulatur. Virchows Arch. path. Anat. 327, 112-126 (1955) 
Hendley, D., Mildvan, A., Reporter, M., Strehler, B.: The properties of isolated human cardiac age pigment. II. Chemical and enzymatic properties. J. Gerontol. 18, 250-259 (1963)

Hess, A.: The fine structure of young and old spinal ganglia. Anatomical record 123, 399-423 (1955)

Hirosowa, K.: Electron microscopic studies on pigment granules in the substantia nigra and locus coeruleus of the Japanese monkey (Macaca fuscata yakui). Z. Zellforsch. 88, 187-203 (1968)

Karnaukhov, V.N., Tataryunas, T.B., Petrunyaka, V.V.: Accumulation of carotenoids in brain and heart of animals on aging; the role of carotenoids in lipofuscin formation. Mech. Age. Dev. 2, 201210 (1972)

Kikuchi, K.: Uber die Altersveränderungen am Gehirn des Pferdes. Arch. wiss. prakt. Tierheilkunde 58, 541-573 (1928)

Koeppen, A.H., Barron, K.D., Cox, J.F.: Striatonigral degeneration. Acta neuropathol. 19, 10-19 (1971)

Leibnitz, L., Wünscher, W.: Die lebensgeschichtliche Ablagerung von intraneuralem Lipofuscin in verschiedenen Abschnitten des menschlichen Gehirns. Anat. Anz. 121, 132-140 (1967)

Lubarsch, O.: Uber das sogenannte Lipofuscin. Virchows Arch. 239, 491-503 (1922)

Miyagashi, T., Takahata, N., Iizuka, R.: Electron microscopic studies on the lipopigments in the cerebral cortex nerve cells of senile and vitamin-E-deficient rats. Acta neuropathol. 9, 7-17 (1967)

Nanda, O.S., Getty, R.: Lipofuscin pigment in the nervous system of aging pig. Exp. Gerontol. 6, 447452 (1971)

Nandy, K.: Properties of neuronal lipofuscin pigment in mice. Acta neuropathol. 19, $25-32$ (1971)

Obersteiner, H.: Uber das hellgelbe Pigment in den Nervenzellen und das Vorkommen weiterer fettähnlicher Körper im Centralnervensystem. Arbeiten aus dem neurologischen Institut Wien 10, 245-274 (1903)

Palay, S.L., Chan-Palay, V.: Cerebellar cortex. Berlin-Heidelberg-New York: Springer Verlag 1974

Pearse, A.G.E.: Histochemistry, Vol. II. London: Churchill Livingstone 1972

Reichel, W., Hollander, J., Clark, J.H., Strehler, B.L.: Lipofuscin pigment accumulation as a function of age and distribution in rodent brain. J. Gerontol. 23, 71-78 (1968)

Romeis, B.: Mikroskopische Technik. München: Oldenbourg 1948

Roy, S., Wolman, L.: Ultrastructural observations in Parkinsonism. J. Pathol. 99, 39-44 (1969)

Samorajski, T., Ordy, J.M., Rady-Reimer, P.: Lipofuscin pigment accumulation in the nervous system of aging mice. Anatomical Record 160, 555-574 (1968)

Schlote, W., Boellaard, J.W.: Alterskorrelierter Strukturwandel des neuronalen Lipopigments beim Menschen. Verh. Dtsch. Ges. Path. 59, 304-309 (1975)

Siakotos, A.N., Goebel, H.H., Patel, V., Watanabe, I. Zeman, W.: The morphogenesis and biochemical characteristics of ceroid isolated from cases of neuronal ceroid-lipofuscinosis. In: Sphingolipids, Sphingolipidosis and allied disorders (W.B. Volk, S.M. Arson, eds.), pp. 53-61. New York: Plenum Press 1972

Siakotos, A.N., Koppang, N.: Procedures for the isolation of lipopigments from brain, heart and liver and their properties. A review. Mech. Age. Dev. 2, 177-200 (1973)

Singer, P.A., Cate, J., Ross, J., Netsky, M.G.: Melanosis of the dentate nucleus. Neurology 24, 156-161 (1974)

Tcheng, Kuo-tschang: Some observations on the lipofuscin pigments in the pyramidal and Purkinje cells of the monkey. J. Hirnforsch. 6, 321-326 (1964)

Wall, G.: Uber ein Lipofuscin transportierendes Pigmentzell-System in der Kleinhirnrinde der Katze. Z. Anat. Entwickl.-Geschl 143, 13-24 (1973)

Whiteford, R., Getty, R.: Distribution of lipofuscin in the canine and porcine brain as related to aging.J. Gerontol. 21, 31-44 (1966) 